\title{
Commercialisation of Religion in Neo-Prophetic Pentecostal/Charismatic Churches in Ghana: Christian Ethical Analysis of their Strategies
}

\author{
George Anderson Jnr. \\ Department of Religion and Human Values, University of Cape Coast, Ghana
}

\begin{abstract}
Neo-Prophetic Pentecostal/Charismatic Christianity in Ghana has become business. It is typically characterised by the sale and purchase of assortments of religious items and services between churches and religious consumers. This practice is said to have experienced its exponential index in view of the utmost demand for miraculous mediation by desperate religious consumers to address their religio-psycho-social pickles. Irrespective of the abuses religious consumers are said to go through, coupled with the high cost the religious items and services are sold, one is curious to ascertain by what means the churches use to hook religious consumers to their offers. This paper thus, sets out to reveal and analyse some of the main strategies NeoProphetic Pentecostal/Charismatic churches in Ghana use to hook religious consumers onto their offers using Christian ethics as assessment criteria. The paper argues that the strategies the churches use are not in conformity with Christian ethics, thus, they are unethical. This is because it was revealed that the intentions that drive the strategies are mostly geared towards selfish, domineering and manipulative end.
\end{abstract}

Keywords: Ghana, religion, commercialisation, Neo-Prophetic Pentecostal/Charismatic Churches, strategies, Christian ethics.

DOI: $10.7176 / \mathrm{JPCR} / 42-01$

Publication date:March $31^{\text {st }} 2019$

\section{Introduction}

Over the years, Ghana has witnessed a proliferation of churches. Such churches are of the Pentecostal, Charismatic and Neo-Prophetic genres. This proliferation of churches has sparkled among themselves religious competition. In this competition, each church tries to outdo the other by putting up attractive strategies, and religious products and services that are likely to aid them to acquire new members and to retain the already existing ones. Given the economic hardships in Ghana, the religious worldview of Ghanaians and religious consumers' pursuit of prosperous life and to be free from malevolent spirits, majority of Ghanaian religious consumers happen to be fascinated by the strategies, thus express exponential demand for the religious products and services the churches offer. The general belief which is held by the religious consumers is that such religious products and services have supernatural potency to remedy their religio-psycho-social pickles.

This situation has given rise to religious opportunism and interdependency, where domineering and materialistic religious leaders take advantage of the religious artlessness, vulnerability and gullibility of desperate religious consumers to enrich themselves and to condition the minds of religious consumers to solely depend on them for their supernatural remedies to their problems. This interaction has therefore generated into the sale and purchase of religious products and services between Neo-Prophetic Pentecostal/Charismatic churches and desperate Ghanaian religious consumers. Whereas in this commercial interaction, religious consumers are said to go through several abuses and also they purchase the religious products and services at exorbitant prices, religious consumers appear not to be discouraged or perturbed. Rather, they continue to express exponential demand for the services and religious products. This raises the question; by what strategies do the churches use to continue to hook religious consumers to their offers irrespective of the abuses and the exorbitant prices of their services and products. This paper thus, sets out to reveal and analyse some of the main strategies Neo-Prophetic Pentecostal/Charismatic churches in Ghana use to hook religious consumers onto their offers using Christian ethics as assessment criteria.

Methodologically, the paper was approached phenomenologically, paying close adherence to the principles of epoché and eidetic intuition to be able to deal with the subject matter holistically without being unnecessarily judgmental. Data were mainly collected through participatory observation in Ebenezer Miracle Worship Centre, Kumasi in the Ashanti Region of Ghana with supplementary data from International God's Way Church (Kumasi), Anointed Palace Chapel (Kumasi), and House of Prayer for All Nations (Cape Coast, Central Region). The data were analysed using Christian ethical principles. The paper is significant because it contributes to literature on Neo-Prophetic Pentecostal/Charismatic Christianity in Ghana which has received scanty scholarship.

\section{Commercialisation of Religion}

'Commercialisation of religion' is also depicted by scholars as church commercialisation, ecclesiastic marketing, 
church marketing, and religious marketing. In The Divine Deceit: Business in Religion, Fidelis K. Obiora as cited by Princewell A. Nwanganga ${ }^{1}$ observed that the term church commercialisation first, designates the application of commercial/business principles to run a church as a business entity with the intent of making economic gains. Second, the author intimated that the term depicts the manipulation of church/Christianity, its services (spiritual and emotional) with the motive of exploiting church members or prospects for economic or financial gain. One weakness in this definition is that, the author confines the term to any business-like interaction between a church and its members. Yet, commercialisation of religion is not restricted to Christianity; it is also reflected in other religions such as Islam and African Traditional Religion ${ }^{2}$. Furthermore, religious consumers from other religions involve themselves in commercialisation of religion with a particular religious group that commercialises religion. In the research units, I gathered that the religious consumers who were engaged in the commercialisation process came from other churches and religious fraternities. In that sense, it would be appropriate to depict 'commercialisation of religion' as the sale and purchase of religious products and services between a given religion and religious consumers.

Fidelis K. Obiora's explanation to the term resonates with Ann Sherman and James F. Devlin ${ }^{3}$ who in American and British Clergy Attitudes Towards Marketing Activities: A Comparative Study, showed that church commercialisation or 'ecclesiastic marketing' involves the application of marketing techniques in order to spread a religion, to attract proselytes and to obtain loyalty. The authors argued that this method is increasingly used by different religious groups, through specific institutions such as churches or praying buildings and missions in order to get the wanted answer from a target market. For them, religious leaders stick to the 'Seven P Formula' i.e. product, price, promotion, place, packaging, positioning, and people to sell religion to their targeted group. Princewell A. Nwanganga ${ }^{4}$ on his part has observed that church commercialisation means every action, activities of church leaders, pastors, and prophets, that have economic or profit making annotation. From the author's exposition one can gather that church commercialisation means converting the church's core mandate of soul winning, attending to spiritual and emotional needs of church members with the primary aim of accruing financial gains and wealth. According to Pius O. Abioje ${ }^{5}$, commercialisation of religion is an activity that involves individuals and religious organisations where each does everything for making a living, whether on the short or long term. In this activity, both parties search for fulfilment in order to survive. Individuals search for supernatural remedies to their existential problems whereas religious organisations also advertise and provide the supposed 'supernatural remedies'. Using the Nigerian religious scene as a case study, the author revealed that the mass communication media, such as the press, radio, television, audio and video cassettes, tracts, pamphlets and books are the predominant media religious organisations use to make their religious products known.

Apart from ecclesiastic marketing, there is, 'church marketing'. Robert E. Stevens, et. al ${ }^{6}$ in Concise Encyclopedia of Church and Religious Organisation Marketing, observed that church marketing involves a religious engagement between churches and members where religious products and services for sale are made available to members. This type of marketing involves an analysis, planning, and management of voluntary exchange between a church or religious organisation and its constituents for the purpose of mutual satisfaction of needs. In addition, church marketing concentrates on the analysis of constituents' needs, developing programs to meet these needs, providing these programs at the right time and place, communicating effectively with constituents, and attracting the resources needed to underwrite the activities of the organisation. It can be inferred from the above discussions that commercialisation of religion depicts an interaction that involves the sale of religious products and services to consumers of religion by a particular religion facilitated in a church, mosque or a shrine. In this interaction, churches/mosques/shrines use varieties of attractive and efficient business marketing strategies to attract and win the attention of consumers of religion. One important point that needs to be stressed here is that 'commercialisation of religion', and 'religious commercialisation' are two different concepts. The former, means the sale of religious products and services to religious consumers, whereas the latter implies the religious way of selling items/products and services to people who may or may not be religious consumers. It is important to distinguish between these two terms so that they are not understood synonymously.

\footnotetext{
${ }^{1}$ Princewell A. Nwanganga, Church Commercialization in Nigeria: Implications for Public Relations Practice. Journal of Philosophy, Culture and Religion, 28, (2017): 3

${ }^{2}$ See: Rana Eijaz Ahmad \& Abida Eijaz, Commercialisation of Religion in Pakistan. American International Journal of Contemporary Research, 1, 2, (2011): 186-189.

${ }^{3}$ Ann Sherman \& James F. Devlin, "American and British Clergy Attitudes towards Marketing Activities: A Comparative Study", The Service Industries Journal, (2000): 49.

${ }^{4}$ Princewell A. Nwanganga, Church Commercialization in Nigeria, 3.

${ }^{5}$ Pius Oyeniran Abioje, "The Mass Media and Commercialisation of Religions in Nigeria". Multidisciplinary Journal of Research Development, 6, 1, (2005): 40.

${ }^{6}$ Robert E. Stevens, David L. Loudon, Bruce Wrenn, \& Henry Cole. Concise Encyclopedia of Church and Religious Organization Marketing. New York: The Haworth Reference Press, (2005): 77.
} 


\section{Religious Consumers Involved in Commercialisation of Religion}

The phenomenon of commercialisation of religion is a complex one. This is because it appears somewhat difficult to ascertain who has or has not a demand for religion. This means, it is probably not everyone who is seen to partake in commercialisation of religion that has demand for religion and its accretions. This point is very crucial to emphasise because it would be an erroneous perception to perceive of anyone who partakes in commercialisation of religion with a church/mosque/shrine to have a demand for religion.

In the research units, I gathered that there were people who partook in commercialisation of religion but did not necessarily have demand for religion. These were people who desired to ascertain the main religious items commercialised for news reportage and research/academic reasons. But, these people usually formed the minority, whiles the majority who have demand for; and perceive religion to be the panacea to their problems were discovered to be the main religious consumers involved in commercialisation of religion. I gathered that barren women, impotent men, pastors/prophets from other churches; people who are afraid of malevolent spirits, nurses, teachers, students, police officers, the aged, visually impaired, the sick, cripple, the accursed, pregnant women, children, politicians and the unemployed are religious consumers involved in the sale and purchase of religious products in Neo-Prophetic Pentecostal/Charismatic churches in Ghana. These religious consumers were identified as people who have social, religious, psychological, emotional, political, health, educational, and economic/financial needs and perceive religion as the sole panacea to their predicaments.

\section{Commercialisation Strategies by Neo-Prophetic Pentecostal/Charismatic Churches in Ghana}

The search for a niche, hegemony, large following and fame in Ghana's religious field has put Neo-Prophetic Pentecostal/Charismatic pastor/prophets under pressure to search for attractive strategies to get people into their fold and to maintain existing members. Studies ${ }^{1}$ in Ghana have shown that Pentecostal/Charismatic churches adopt business marketing principles in their operations to enable them to become increasingly important, conspicuous and attractive to religious consumers. One of such strategies is the use of media (television, radio and print). Appiah Sarpong, Gabriel Dwomoh and Lydia Asare Kyire ${ }^{2}$ in The Relationship between Church Marketing and Church Growth: Evidence from Ghana, revealed that using independent variables such as advertising, congregants' recommendation and public relation, there exists a positive correlation between the independent variables and church attendance growth in Ghana. The authors showed that 'Radio Public Relations' marketing tool is most efficient and it influences growth in church membership. Victoria Acheampong ${ }^{3}$ has also identified personal selling, direct marketing, and sales promotion as strategies churches use. The author argued that the variables bring the products and services closer to the doorstep of religious consumers. Furthermore, the said strategies open an interactive avenue for the religious consumer to seek clarification, scrutinise and examine the products that serve his/her interest. In Ebenezer Miracle Worship Centre like the other Neo-Prophetic Pentecostal/Charismatic churches in Ghana, I identified testimonies given by users of the religious products and services, and Prophet Ebenezer Adarkwa Yiadom and his associate pastors as one of the strategies the church uses to attract and convince religious consumers to partake in the commercialisation process. In the church, I observed time without number the testimony the Prophet personally gives about the religious products, and the congregants who gave testimonies about how efficacious the Separator of fight and collector of fights, Ppata ko agye ko abswobo and Iron cuts iron, Dadie bi twa dadie anointing oils have helped them to remedy their pickles.

Television and radio programmes were also identified as one of the strategies used. The programmes are usually characterised by phone-in segments; and discussions made by the Prophet and his associate pastors on the nature and efficacy of the religious products and services the church offers to allay the problems of people. Apart from this, they also telecast miraculous healings of sick persons such as the blind, cripple and deaf. Having shown these scenes, they try to convince viewers that, it only takes a miracle and a prophetic intervention of an authentic prophet like Prophet Ebenezer Adarkwa Yiadom to bring remedy to a person's problem. Apart from television and radio programmes, Neo-Prophetic Pentecostal/Charismatic churches in Ghana use fear as a strategy to get religious consumers to buy their religious products. They usually stress on the negative roles enemies, atamfo including witches and wizards play to cause failures and chronic problems in people's lives. They also add that evil spirits are in constant scuffle with people's prosperity, marriages, and businesses. Thus, the only way to get rid of one's enemies, atamfo is to use the Separator of fight and collector of fights, Jpata ko agye ko abowobo and Iron cuts iron, Dadie bi twa dadie anointing oils.

Weekly counselling service was identified as one of the strategies Neo-Prophetic Pentecostal/Charismatic churches use. Counselling in Neo-Prophetic Pentecostal/Charismatic Churches is purposely done for religious consumers to be told the causes and remedies to their predicaments. In most cases, the causes and the

\footnotetext{
${ }^{1}$ See: Appiah Sarpong, Gabriel Dwomoh, \& Lydia Asare Kyire, The Relationship between Church Marketing and Church Growth: Evidence from Ghana. Global Journal of Marketing and Business Research Marketing, 13, 10, (2013); Victoria Acheampong, The Effects of Marketing Communication on Church Growth in Ghana. Unpublished PhD Thesis, University of Ghana, Legon, (2014).

${ }^{2}$ Appiah Sarpong, Gabriel Dwomoh, \& Lydia Asare Kyire, The Relationship between Church Marketing and Church Growth, 8

${ }^{3}$ Victoria Acheampong, The Effects of Marketing Communication on Church Growth in Ghana, v.
} 
explanations the prophets provide to their clients are religiously contextualised. This makes it very difficult for their clients to refuse any instruction and demands of the prophets. In fact, some predicaments do not necessary have anything to do with religion. They are purely science-related issues which should be addressed using scientific or indigenous medical approaches. However, for Neo-Prophets to get their clients to buy their religious items, they contextualise every predicament in a religious perspective and recommend their religious products as the only panacea to such predicaments. Prosperity, yiedie and anointing, ngosra are also strategies NeoProphetic Pentecostal/Charismatic churches use. Neo-Prophets/Pastors stress and elucidate the need for a Christian to have God's anointing ${ }^{1}$ to be able to become prosperous ${ }^{2}$ in the midst of the economic difficulties in Ghana. In Ebenezer Miracle Worship Centre like the other Neo-Prophetic Pentecostal/Charismatic churches involved in this study, the prophets/pastors stress on the above concepts daily. In some cases, they give lottery numbers and drop anointing oil in congregants' palms and collect money.

Aside the above, Neo-Prophetic Pentecostal/Charismatic prophets/pastors discredit, scandalise and demonise the religious practices, items and pastors/prophets in other religious denominations, and project themselves as the true and authentic ones. In Ebenezer Miracle Worship Centre for instance, I observed time without number many instances where Prophet Adarkwa Yiadom and his associate pastors depicted prophets/pastors who do not belong to Ebenezer Miracle Worship Centre as tricksters, occultists and fake. They believe pastors/prophets who do not belong to their church manipulate desperate religious consumers to buy fake religious products and services in those churches. On the basis of ethics, Prophet Ebenezer Adarkwa Yiadom hardly mentions the names of the pastors/prophets he considers as tricksters, occultists, and fake. Conversely, it is inferable that those so-called dubious pastors/prophets are his rivalries. These ill-comments psychologically influence congregants to patronise any religious item and services he sells to them. In fact, he is also hyped and regarded as the archetype of morality. In other words, he is not susceptible to mistakes. Anything he does or says is right and no one has the moral right to question his authority, actions and inactions. This is reflected in how he uses vulgar and abuse words, and reprimands congregants, church workers, and his associate pastors who go contrary to his rules. This situation has made the congregants to solely, and regularly depend on the religious products and services he sells, and he is therefore regarded as the saviour to their problems.

\section{Religious Products and Services Neo-Prophetic Pentecostal/Charismatic Churches Sell in Ghana}

Joy Hendry ${ }^{3}$, and Russell Belk, Melanie Wallendorf, and John Sheryy ${ }^{4}$ explicate religious or sacred items as tangible and intangible things that are symbolically linked with and objectify the sacred. In other words, religious products are sacred things that have religious significance, value, and are used to enhance religious performances. The rosary, crucifix, Bible, Qur'an, Tasbih, talisman, wand, amulets, and holy water are some examples of tangible religious products. There are also magic formulae, dances, crests, names, and songs that are some examples of intangible religious products. These items are normally approached with both attraction and fear.

An important dimension to the explanation of religious products the scholars above seem to overlook is the fact that there are some items that may not necessarily have any symbolic link with, and objectifies the sacred but can be made a religious item through prayers so as to have a symbolic link to objectify the sacred. It is in the light of this weakness in the definition of religious products that this paper extends the definition scope. In that sense, the term religious item/product as used in this paper means any item/product with or without a religious value and significance but has been prayed over by a prophet or pastor to have a symbolic link with, and objectifies the sacred. Some examples include bottled mineral water, soft drink (Fanta, Coca Cola, and Sprite), anointing oil, sticker, holy water, rice, handkerchiefs, anointed eggs, fruits (oranges, banana, pineapple), brassieres, Well-water, Aburamu Nsuo ${ }^{5}$, and headgear. It is important to mention these items. This is because Neo-Prophetic Pentecostal/Charismatic pastors/prophets use them as a medium to effect healing and address people's needs.

Brenda Gainer and Paulette Padanyi ${ }^{6}$ have shown that Pentecostal/Charismatic churches commercialise

\footnotetext{
${ }^{1}$ See: Roland Owusu-Ansah, The Usage of Anointing Oil in some Charismatic and Neo-Prophetic Churches in Kumasi in the Context of Leviticus 8:1-12 and James 5:14-15. Unpublished MPhil Thesis, Kwame Nkrumah University of Science and Technology, Kumasi, (2011): 109; Paul Gifford, Ghana's New Christianity: Pentecostalism in a Globalizing African Economy. Indiana: University Press, (2004): 56, 60; David B. Stiles-Ocran, "Prophetism in Ghana: A Case Study of some Charismatic Churches". Unpublished PhD Thesis, University of Ghana, Legon, Accra, (2004): 96.

${ }^{2}$ See: Gideon Tetteh, Analysing Perspectives on Evil, Enemy and Divinatory Consultation among Participants in Neo-Prophetic Movements in Pentecostal Ghana. M.Phil. in Intercontextual Theology, University of Oslo, (2016): 80.

${ }^{3}$ Joy Hendry, An Introduction to Social Anthropology: Other People's Worlds. London: Palgrave Macmillan Press Ltd., (1999): 38.

${ }^{4}$ Russell Belk, Melanie Wallendorf, and John Sheryy, The Sacred and the Profane in Consumer Behavior. Journal of Consumer Research, 6, (June 1989):11.

${ }^{5}$ Aburamu Nsuo as is an Asante Twi rendition of water extracted from a well, which is located in the premises of Ebenezer Miracle Worship Centre. It is believed that the water in the well has the power to heal disease, and to protect people from their atamfo, and witches/wizards.

${ }^{6}$ Brenda Gainer, \& Paulette Padanyi, Applying the Marketing Concept to Cultural Organisations: An Empirical Study of the Relationship between Market Orientation and Performance. International Journal of Non-profit \& Voluntary Sector Marketing, 7, 2, (2002): 182-193.
} 
fertility. Linking this to the Ghanaian situation, Appiah Sarpong, Gabriel Dwomoh, and Lydia Asare Kyire have observed that there is high expectation of child bearing by parents of married couples in Ghana. This expectation is generally the fruit of the high prices for bride price taken before marriage. This is why it becomes a "bad market" when the woman fails to give birth. In fact, the religious climate in Ghana often leads most women who fail to give birth to seek help from Pentecostal/Charismatic Pastors, and Neo-Prophetic Prophets. Pastors/Prophets of these churches often provide explanations for such women's infertility within a religious context. In this religious context, women are required to buy a Christian religious item prepared and sold by the pastor to enable her to become productive ${ }^{1}$. In International God's Way Church for instance, childless couples are often given toffees popularly called 'baby toffees' to be eaten after which they give an offertory ${ }^{2}$.

Aside fertility, Neo-Prophetic Pentecostal/Charismatic churches commercialise salvation. Appiah Sarpong et. al. argue there are several ways that Pentecostal/Charismatic churches approach the understanding and attainment of salvation. In one sense, salvation is understood as the state where a person attains eternal bliss with God. Perspectively, Neo-Prophetic Pentecostal/Charismatic churches stress on righteousness as the condition for achieving salvation. Salvation for the Neo-Prophetics means moving from a state of danger to a peril-free state. Such peril could be provoked by natural phenomena like a storm, hunger, sickness, a human enemy, or malevolent spirit ${ }^{3}$. The latter understanding of the concept of salvation as, moving from a state of danger to a peril-free state appears to influence Neo-Prophetic Pentecostal/Charismatic Churches to emphasise on the use and patronisation of Christian religious products and services. Hence, for one to be saved, one is required to buy the religious products that are offered for sale.

In Ghana, prophets in Neo-Prophetic Pentecostal/Charismatic churches demonstrate by way of life and pronouncement that salvation is not free. Rather, it must be bought. Additionally, the activities of malevolent spirits cause one to lose one's salvation ${ }^{4}$. This perception affects and influences church members and other customers of religion to engage in commercialisation of religious products with Neo-Prophetic Pentecostal/Charismatic churches. This engagement aims at helping people to be saved from malevolent spirits that torment their lives and cause them to lose their salvation.

Anointing oil is another religious item Neo-Prophetic Pentecostal/Charismatic churches sell in Ghana ${ }^{5}$. In Ebenezer Miracle Worship Centre Prophet Ebenezer Adarkwa Yiadom sells a bottle of Iron cuts iron, Dadie bi twa dadie anointing oil for $\mathrm{GH} ф 20, \mathrm{GH} \phi 50, \mathrm{GH} ф 100$ and $\mathrm{GH} ф 200$, and Separator of fights and collector of fights, Jpata ko agye ko abswobo (anointing oil and eggs) for GH $\notin 500, \mathrm{GH} ф 1,000$, and $\mathrm{GH} ф 2,000$. There are other oils such as back to sender, light for my path, me kwan so hann, fire quencher, odumgya, and wrestling, atentam $^{6}$ that Neo-Prophetic Pentecostal/Charismatic churches sell to their clients. These oils are believed to possess supernatural powers that enhance businesses, protect and resist malevolent spirit attacks, provide favour, and render successes to users. Apart from anointing oil, personal meeting with a prophet/pastor is said to be commercialised by Neo-Prophetic Pentecostal/Charismatic churches in Ghana. Some Neo-Prophets charge their clients about GHф $200-1000$ (US\$ 50 - 200) as consultation fees before they listen to the plights of their clients $^{7}$. Neo-Prophetic Pentecostal/Charismatic pastors/prophets prepare are soaps, perfumes, wristlets, brassieres, and handkerchiefs that have the imprints of the picture of the pastor/prophet and sell them to their clients adding that anyone who uses the items is rest assured of protection from malevolent spirits.

\section{Christian Ethical Analysis of the Strategies}

Ethics deal with standards of right and wrong established and imposed on members in and by a particular society. Such standards regulate and set limits on the behaviour of the members in that society ${ }^{8}$. One important point that must be emphasised here is that ethics question and provide the justifications (i.e. the why and on what grounds) for the judgment passed on the actions of the moral agent who belongs to the said group ${ }^{9}$. By ethics, I refer to Christian ethics, which is the point of reference for analysing the strategies Neo-Prophetic Pentecostal/Charismatic churches have adopted to commercialise religion in Ghana. Christian ethics, centre on the rightness and wrongness of human acts and have its basis from Jesus Christ ${ }^{10}$. In other words, Christian

\footnotetext{
${ }^{1}$ Appiah Sarpong, Gabriel Dwomoh, \& Lydia Asare Kyire, The Relationship between Church Marketing and Church Growth: Evidence from Ghana. Global Journal of Marketing and Business Research Marketing, 13, 10, (2013): 11.

${ }^{2}$ Personal Interview by George Anderson Jr. on February 18, 2018, with 5 childless women who conceived after eating the "baby toffee" at International God's Way Church, Accra Branch.

${ }^{3}$ Sarpong Appiah, Gabriel Dwomoh \& Lydia Asare Kyire, The Relationship between Church Marketing and Church Growth: Evidence from Ghana. Global Journal of Marketing and Business Research Marketing, 13, 10, (2013): 11.

${ }_{4}^{4}$ Karen Lauterbach, Wealth and Worth: Pastorship and Neo-Pentecostalism in Kumasi, Ghana Studies, 9, (2006): 91.

${ }^{5}$ Jonathan E. T. Kuwornu-Adjaottor, Contemporary Prophetism in Kumasi: A Sociocultural and Theological Assessment. Herald Journal of Education and General Studies, 2, 1, (2013): 64

${ }^{6}$ Roland Owusu-Ansah, The Usage of Anointing Oil in some Charismatic and Neo-Prophetic Churches in Kumasi, 154

${ }^{7}$ Jonathan E. T. Kuwornu-Adjaottor, Contemporary Prophetism in Kumasi, 64.

${ }^{8}$ Judith A. Boss, Ethics for Life: A Text with Readings, (4 ${ }^{\text {th }}$ ed.). New York: McGraw-Hill, (2008): 6.

${ }^{9}$ See Joseph Migga Kizza, Ethical and Social Issues in the Information Age, (4 ${ }^{\text {th }}$ ed.). New York: Springer, (2010): 33

${ }^{10}$ Daniel R. Heimbach, Toward Defining Christian Ethics: An Evaluation of Contrasting Views. Global Journal of Classic Theology, 8, 3 ,
} 
ethics deal with the life, teachings and principles of Jesus Christ which are the standards for every Christian adherent, church, or Christian group. This means, anyone or group of people who see Jesus Christ as the source and summit of their ethos must conform to his way of life, teachings and principles. Thus, any behaviour or way of life that go contrary to that of Jesus Christ is unethical.

Christian ethics abhor fear, one of the strategies identified to be used by Neo-Prophetic Pentecostal/Charismatic Churches in Ghana. Christian ethics advocate for the use of one's free will to choose to perform an action or not, given the situation at hand. This means when one uses fear to influence the behaviour of another to either perform an action or not unwillingly is unethical. According to Lucius M. Plutarch as cited by Frank Cole Babbitt, 'fear' regulates a person's religious behaviour by clouding his/her judgement and ability to fruitfully reason ${ }^{1}$. Thus, fear as strategy employed by Neo-Prophetic Pentecostal/Charismatic churches to influence religious consumers to hook them onto their religious products and services is unethical. This is because the intention behind this strategy goes contrary to Jesus' teachings and way of life, which is the point of reference for Christian ethics.

Christian ethics advocate for love for one's neighbour and not to be judgemental ${ }^{2}$. Yet, Neo-Prophetic Pentecostal/Charismatic prophets/pastors use their media platforms and also stand in their churches to discredit, scandalise and demonise the religious practices, religious items and pastors/prophets in other religious denominations, and project themselves as the true and authentic ones. This strategy adopted to divert the attention of religious consumers from patronising the services of prophets/pastors in other churches is unfortunate, simplistic and unethical, since the approach goes contrary to the ethical principles of Jesus Christ who advocates for love for one's neighbour and for a person not to be a judge over his/her fellow human being.

I gathered from the Neo-Prophetic Pentecostal/Charismatic churches that they dwell on testimonies from users of their religious items and services to get other religious consumers to also buy. It must be underscored that ethically, it is not out of place for a person to give a testimony in church to encourage others to be confident to know how to tackle their predicaments. However, it can be argued that Christian ethics are breached when people and their testimonies are used as a means to an end. This means that inasmuch as Neo-Prophetic Pentecostal/Charismatic prophets/pastors put their clients under camera and use their testimonies as a bait to get other people to buy their religious products and patronise their service, there is reason to argue that such strategy defies the Christian ethical principle of treating humans as an end in themselves but not as a means to an end ${ }^{3}$.

Counselling session offered by Neo-Prophetic Pentecostal/Charismatic prophets/pastors is not a bad thing. But the motive for organising counselling session is what interests this paper for Christian ethical analysis. In fact, my argument is that counselling is a covert manipulative device Neo-Prophetic Pentecostal/Charismatic prophets/pastors have adopted to get religious consumers to buy their religious products and to patronise their services. In Neo-Prophetic Pentecostal/Charismatic churches, it is very difficult to have personal interaction with the head prophet/pastor unless the day slated for counselling session. During counselling sessions in NeoProphetic Pentecostal/Charismatic churches, prophets provide religious explanations to every predicament of their clients. Arguably, there are some predicaments such as abnormal menstrual pain, chronic stomach ache, back ache and impotency that need to be addressed medically. Yet, the prophets dwell on the religious worldview of Ghanaians that every mishap has a spiritual dimension and manipulate their clients so that they buy their expensive religious items. In fact, this unscrupulous intention as covertly formulated into the counselling session is unethical regardless of the supposed benefit the service brings to religious consumers. This is because Christian ethics abhor manipulation and extortion of people's resources.

From the preceding analysis, it has become clear that the motive/intention and the approach to any action are very crucial to Christian ethics. This is because Christian ethics are concerned with the means to an end but not the necessarily the end of an action. In other words, in Christian ethics, it is the means that justify the end, but not the end that justifies the means. This means that Neo-Prophetic Pentecostal/Charismatic churches in Ghana must adopt strategies that are in line with the ethical principles of Jesus Christ who is the source and summit of Christian ethics, the model for Christians and churches.

\section{Conclusion}

This paper has shown and more significantly from Christian ethical perspective analysed some of the main strategies Neo-Prophetic Pentecostal/Charismatic churches in Ghana use to hook religious consumers onto their religious items and services. The paper was motivated on the premise that Neo-Prophetic

(2011): 16

${ }^{1}$ Frank Cole Babbit, (Ed. and Trans. in English). Plutarch's Moralia, vol. VI, London: Cambridge Mass, (1938).

${ }^{2}$ See: Matthew 7:1 RSV Bible.

${ }^{3}$ See: Judith A Boss, Analyzing Moral Issues. London, Mayfield Publishing Company, (1999): 25. See: Agnes Quansah, A Theological and Ethical Study of Loud Christian Prayer on The University of Ghana Campus, Legon. Unpublished M.Phil Thesis, University of Ghana, Legon, (2013): 73; George Anderson Jnr. \& Joseph Oppong, Wife Battery: A Divine Command from the Garden of Eden or a Gene Disorder in Men? Ethical Perspectives. American Journal of Social Issues and Humanities, 6, 4, (2016): 889. 
Pentecostal/Charismatic Christianity in Ghana today has become business, which is typically characterised by the use of dubious strategies by prophets/pastors to sell assortments of religious items and services to religious consumers who appear to be desperate. Given the abuses, exorbitant charges levied on the sale of religious products and services, Jesus' reservations about the sale and purchase of religious products and services and the great commission as reflected in Acts 1:8 and Matthew 28:18-18; that the followers of Jesus Christ should teach, baptize and show people the way into God's kingdom, one expects to see Ghanaian prophets/pastors adhere to ethos of Jesus Christ. Yet, the opposite pertains. It is in view of this worrying situation that this paper sought to analyse the strategies Neo-Prophetic Pentecostal/Charismatic churches in Ghana use to get religious consumers to buy their religious items and patronise their services using Christian ethics as assessment criteria. The preceding analysis has shown that the strategies Neo-Prophetic Pentecostal/Charismatic churches use are unethical. This is because they are covertly informed by selfish, domineering and manipulative end which do not conform to the ethical principles of Jesus Christ. In that perspective, the paper suggests that Neo-Prophetic Pentecostal/Charismatic prophets/pastors should discontinue the sale of religious products and services, focus on the Christian mandate and to teach the Ghanaian citizenry to be morally upright citizens who should eschew corrupt practices to enable the country to experience rapid socio-economic development. Furthermore, Ghanaian religious consumers should be very circumspect and critically assess churches before they seek from them any spiritual assistance.

\section{References}

Abioje, Pius Oyeniran. "The Mass Media and Commercialisation of Religions in Nigeria". Multidisciplinary Journal of Research Development, 6, 1, (2005).

Acheampong, Victoria. The Effects of Marketing Communication on Church Growth in Ghana. Unpublished PhD Thesis, University of Ghana, Legon, (2014).

Ahmad, Rana Eijaz \& Eijaz, Abida. Commercialisation of Religion in Pakistan. American International Journal of Contemporary Research, 1, 2, (2011).

Anderson, George Jnr. \& Oppong, Joseph. Wife Battery: A Divine Command from the Garden of Eden or a Gene Disorder in Men? Ethical Perspectives. American Journal of Social Issues and Humanities, 6, 4, (2016).

Babbit, Frank Cole. (Ed. and Trans. in English). Plutarch's Moralia, vol. VI, London: Cambridge Mass, (1938).

Belk, Russell., Melanie Wallendorf, and Sheryy, John. The Sacred and the Profane in Consumer Behavior. Journal of Consumer Research, 6, (June 1989).

Boss, Judith A. Analyzing Moral Issues. London, Mayfield Publishing Company, (1999).

Boss, Judith A. Ethics for Life: A Text with Readings, (4 ${ }^{\text {th }}$ ed.). New York: McGraw-Hill, (2008).

Gainer, Brenda \& Padanyi, Paulette. Applying the Marketing Concept to Cultural Organisations: An Empirical Study of the Relationship between Market Orientation and Performance. International Journal of Non-profit \& Voluntary Sector Marketing, 7, 2, (2002): 182-193.

Gifford, Paul. Ghana's New Christianity: Pentecostalism in a Globalizing African Economy. Indiana: University Press, (2004).

Heimbach, Daniel R. Toward Defining Christian Ethics: An Evaluation of Contrasting Views. Global Journal of Classic Theology, 8, 3, (2011).

Hendry, Joy. An Introduction to Social Anthropology: Other People's Worlds. London: Palgrave Macmillan Press Ltd., (1999).

Kizza, Joseph Migga. Ethical and Social Issues in the Information Age, (4 ${ }^{\text {th }}$ ed.). New York: Springer, (2010).

Kuwornu-Adjaottor, Jonathan E. T. Contemporary Prophetism in Kumasi: A Sociocultural and Theological Assessment. Herald Journal of Education and General Studies, 2, 1, (2013).

Lauterbach, Karen. Wealth and Worth: Pastorship and Neo-Pentecostalism in Kumasi, Ghana Studies, 9, (2006).

Nwanganga, Princewell A. Church Commercialization in Nigeria: Implications for Public Relations Practice. Journal of Philosophy, Culture and Religion, 28, (2017).

Owusu-Ansah, Roland. The Usage of Anointing Oil in some Charismatic and Neo-Prophetic Churches in Kumasi in the Context of Leviticus 8:1-12 and James 5:14-15. Unpublished MPhil Thesis, Kwame Nkrumah University of Science and Technology, Kumasi, (2011).

Quansah, Agnes. A Theological and Ethical Study of Loud Christian Prayer on The University of Ghana Campus, Legon. Unpublished M.Phil Thesis, University of Ghana, Legon, (2013).

Sarpong, Appiah., Dwomoh, Gabriel \& Kyire, Lydia Asare. The Relationship between Church Marketing and Church Growth: Evidence from Ghana. Global Journal of Marketing and Business Research Marketing, 13, 10, (2013).

Sherman, Ann \& Devlin, James F. "American and British Clergy Attitudes towards Marketing Activities: A Comparative Study", The Service Industries Journal, (2000).

Stevens, Robert E. David L. Loudon, Bruce Wrenn, \& Henry Cole. Concise Encyclopedia of Church and Religious Organization Marketing. New York: The Haworth Reference Press, (2005). 
Stiles-Ocran, David B. "Prophetism in Ghana: A Case Study of some Charismatic Churches". Unpublished PhD Thesis, University of Ghana, Legon, Accra, (2004).

Tetteh, Gideon. Analysing Perspectives on Evil, Enemy and Divinatory Consultation among Participants in NeoProphetic Movements in Pentecostal Ghana. M.Phil. in Intercontextual Theology, University of Oslo, (2016). 